\title{
Numerical Simulation and Process Package Optimization of a New Type of Citrate Desulfurization System
}

\author{
Tao Hong ${ }^{1}$, Guo Wang ${ }^{1}$ \\ ${ }^{1}$ College of Metallurgy Engineering, Xi'an University of Architecture and Technology, Xi'an 710055, \\ Shaanxi Province, China
}

Keywords: Citrate Desulfurization; Absorb; Numerical Simulation; Memorization

\begin{abstract}
In order to further study the process of flue gas desulfurization by citrate process, A numerical model for the removal of $\mathrm{SO}_{2}$ from packed absorption tower is established by using chemical process simulation software Aspen Plus, The influence of operation parameters on desulfurization efficiency was analyzed and optimized. The simulation results are in good agreement with the literature. The model calculation results show that: The desulfurization rate increases with the increase of $\mathrm{pH}$ value and liquid gas ratio of the absorption liquid; With the increase of inlet mass concentration of $\mathrm{SO}_{2}$ and the increase of inlet flue gas flow rate, The results show that the $\mathrm{pH}$ value and the liquid gas ratio are the main factors affecting the flue gas desulfurization efficiency of citrate process. The established model of citrate flue gas desulfurization process is accurate and reasonable, The simulation results can provide reference and reference for the actual operation of desulfurization system and the influence of various operation parameters on desulfurization efficiency.
\end{abstract}

\section{Modeling and Module Selection}

Such as the establishment process of Aspen model is shown in Figure 1, the desulfurization process is decomposed into three parts: 1) the use of packing section of the absorption tower to strengthen the gas-liquid mass transfer process, sulfur-containing flue gas since the packing tower is entered, the citrate absorption liquid enters from the upper end of the packing tower, gas-liquid reverse contact in the tower, the enhancement of mass transfer process that makes the sulfur dioxide in the flue gas is absorbed by the absorption to meet the national standards, the flue gas is absorbed from the upper end of the packing tower after discharge, the absorption liquor from the bottom and then discharged into the desorption tower to continue treatment, the process selects the RadFrac model simulation; 2) -- from the absorption desorption output by the absorption liquor after entering the heat exchanger absorption desorption tower, rich liquid into self desorption tower top, and high temperature steam in the tower of reverse contact, the sulfur dioxide absorption desorption liquid rich in to In the water vapor, the sulfur containing water flows out from the upper end of the desorption tower, and the product stream is obtained after subsequent treatment. After desorption desorption tower section from lean liquid outflow, the heat exchanger is returned to the absorption section for recycling, the process of selecting RadFrac model simulation; 3) mixer output desorption tower desorption solution is returned to the poor absorption tower for recycling, but in the whole process of absorption liquid will therefore need to loss. Adding citric acid salt fresh absorption liquid, so use the mixer to mix fresh absorption liquid and absorption liquid circulation, the highest degree of economic, so the selection of Mixer module. The corresponding relationships between these modules and the process equipment referred to in this process are shown in table 1. 


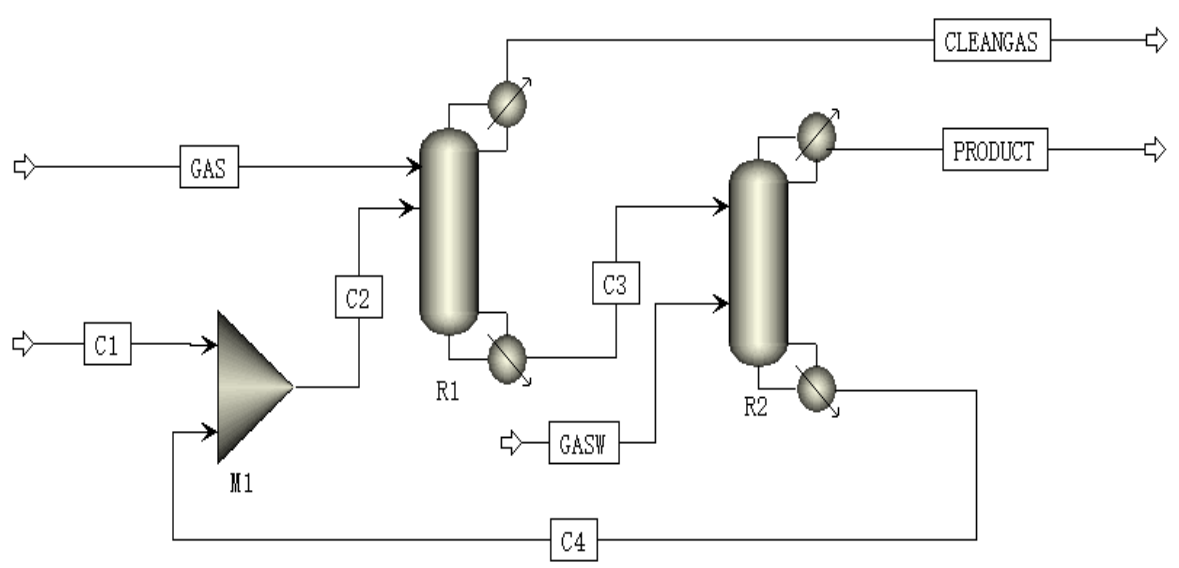

Fig.1. Aspen model flow

Table 1 Relationship between citrate process equipment and Aspen Plus module

\begin{tabular}{|c|c|c|c|}
\hline Citrate process equipment & Absorption section \\
\hline $\begin{array}{c}\text { Aspen } \\
\text { Module legend }\end{array}$ & Desorption section & mixer \\
Aspen & RadFrac & RadFrac & Mixer \\
\hline
\end{tabular}

\section{Regression thermodynamic equilibrium model}

Processing of phase equilibrium experimental data

According to the experimental data of [1] using regression software to carry on the regression function of thermodynamic equilibrium operation, the new Properties-Data in the three data sets, which were named as VLE1, VLE2, VLE3, Setup in Category Phase equilibrium Data type option is selected; choose "TPXY" data type. Fill in the following table, as: 
Table 2 Data-VLE1

\begin{tabular}{|c|c|c|c|c|c|c|}
\hline Usage & TEMPERATURE & PRESSURE & $\mathrm{X}$ & $\mathrm{X}$ & $\mathrm{Y}$ & $\mathrm{Y}$ \\
\hline & $\mathrm{C}$ & $\mathrm{mmHg}$ & $\mathrm{SO} 2$ & $\mathrm{C6H8O} 7$ & $\mathrm{SO} 2$ & $\mathrm{C6H8O7}$ \\
\hline STD-DEV & 0.1 & $0.10 \%$ & $0.10 \%$ & 0 & $0 \%$ & 0 \\
\hline DATA & 40 & 136.6 & 0.006 & 0.994 & 0.022 & 0.978 \\
\hline DATA & 40 & 150.9 & 0.044 & 0.956 & 0.144 & 0.856 \\
\hline DATA & 40 & 163.1 & 0.084 & 0.916 & 0.227 & 0.773 \\
\hline DATA & 40 & 183 & 0.187 & 0.813 & 0.37 & 0.63 \\
\hline DATA & 40 & 191.9 & 0.242 & 0.758 & 0.428 & 0.572 \\
\hline DATA & 40 & 199.7 & 0.32 & 0.68 & 0.484 & 0.516 \\
\hline DATA & 40 & 208.3 & 0.454 & 0.546 & 0.56 & 0.44 \\
\hline DATA & 40 & 210.2 & 0.495 & 0.505 & 0.574 & 0.426 \\
\hline DATA & 40 & 211.8 & 0.552 & 0.448 & 0.607 & 0.393 \\
\hline DATA & 40 & 213.2 & 0.663 & 0.337 & 0.664 & 0.336 \\
\hline DATA & 40 & 212.1 & 0.749 & 0.251 & 0.716 & 0.284 \\
\hline DATA & 40 & 204.6 & 0.885 & 0.115 & 0.829 & 0.171 \\
\hline DATA & 40 & 200.6 & 0.92 & 0.08 & 0.871 & 0.129 \\
\hline DATA & 40 & 195.3 & 0.96 & 0.04 & 0.928 & 0.072 \\
\hline
\end{tabular}

Table 3 Data-VLE2

\begin{tabular}{|c|c|c|c|c|c|c|}
\hline Usage & TEMPERATURE & PRESSURE & $\mathrm{X}$ & $\mathrm{X}$ & $\mathrm{Y}$ & $\mathrm{Y}$ \\
\hline & $\mathrm{C}$ & $\mathrm{mmHg}$ & $\mathrm{SO} 2$ & $\mathrm{C} 6 \mathrm{H} 8 \mathrm{O} 7$ & $\mathrm{SO} 2$ & $\mathrm{C6H}$ O7 \\
\hline STD-DEV & 0.1 & $0.10 \%$ & $0.10 \%$ & 0 & $0 \%$ & 0 \\
\hline DATA & 70 & 548.6 & 0.0065 & 0.9935 & 0.0175 & 0.9825 \\
\hline DATA & 70 & 559.4 & 0.018 & 0.982 & 0.046 & 0.954 \\
\hline DATA & 70 & 633.6 & 0.131 & 0.869 & 0.237 & 0.763 \\
\hline DATA & 70 & 664.6 & 0.21 & 0.79 & 0.321 & 0.679 \\
\hline DATA & 70 & 680.4 & 0.263 & 0.737 & 0.367 & 0.633 \\
\hline DATA & 70 & 703.8 & 0.387 & 0.613 & 0.454 & 0.546 \\
\hline DATA & 70 & 710 & 0.452 & 0.548 & 0.493 & 0.507 \\
\hline DATA & 70 & 712.2 & 0.488 & 0.512 & 0.517 & 0.483 \\
\hline DATA & 70 & 711.2 & 0.625 & 0.375 & 0.597 & 0.403 \\
\hline DATA & 70 & 706.4 & 0.691 & 0.309 & 0.641 & 0.359 \\
\hline DATA & 70 & 697.8 & 0.755 & 0.245 & 0.681 & 0.319 \\
\hline DATA & 70 & 679.2 & 0.822 & 0.178 & 0.747 & 0.253 \\
\hline DATA & 70 & 651.6 & 0.903 & 0.097 & 0.839 & 0.161 \\
\hline DATA & 70 & 635.4 & 0.932 & 0.068 & 0.888 & 0.112 \\
\hline DATA & 70 & 615.6 & 0.975 & 0.025 & 0.948 & 0.052 \\
\hline
\end{tabular}


Table 4 Data-VLE3

\begin{tabular}{|c|c|c|c|c|c|c|}
\hline Usage & TEMPERATURE & PRESSURE & $X$ & $X$ & $\mathrm{Y}$ & $\mathrm{Y}$ \\
\hline & $\mathrm{C}$ & $\mathrm{mmHg}$ & $\mathrm{SO} 2$ & $\mathrm{C} 6 \mathrm{H} 8 \mathrm{O} 7$ & $\mathrm{SO} 2$ & $\mathrm{C} 6 \mathrm{H} 8 \mathrm{O} 7$ \\
\hline STD-DEV & 0.1 & 0 & 0 & 0 & $1 \%$ & 0 \\
\hline DATA & 78.45 & 760 & 0 & 1 & 0 & 1 \\
\hline DATA & 77.4 & 760 & 0.0248 & 0.9752 & 0.0577 & 0.9423 \\
\hline DATA & 77.2 & 760 & 0.0308 & 0.9692 & 0.0706 & 0.9294 \\
\hline DATA & 76.8 & 760 & 0.0468 & 0.9532 & 0.1007 & 0.8993 \\
\hline DATA & 76.6 & 760 & 0.0535 & 0.9465 & 0.1114 & 0.8886 \\
\hline DATA & 76.4 & 760 & 0.0615 & 0.9385 & 0.1245 & 0.8755 \\
\hline DATA & 76.2 & 760 & 0.0691 & 0.9309 & 0.1391 & 0.8609 \\
\hline DATA & 76.1 & 760 & 0.0734 & 0.9266 & 0.1447 & 0.8553 \\
\hline DATA & 75.9 & 760 & 0.0848 & 0.9152 & 0.1633 & 0.8367 \\
\hline DATA & 75.6 & 760 & 0.1005 & 0.8995 & 0.1868 & 0.8132 \\
\hline DATA & 75.4 & 760 & 0.1093 & 0.8907 & 0.1971 & 0.8029 \\
\hline DATA & 75.1 & 760 & 0.1216 & 0.8784 & 0.2138 & 0.7862 \\
\hline DATA & 75 & 760 & 0.1291 & 0.8709 & 0.2234 & 0.7766 \\
\hline DATA & 74.8 & 760 & 0.1437 & 0.8563 & 0.2402 & 0.7598 \\
\hline DATA & 74.7 & 760 & 0.1468 & 0.8532 & 0.2447 & 0.7553 \\
\hline DATA & 74.5 & 760 & 0.1606 & 0.8394 & 0.262 & 0.738 \\
\hline DATA & 74.3 & 760 & 0.1688 & 0.8312 & 0.2712 & 0.7288 \\
\hline DATA & 74.2 & 760 & 0.1741 & 0.8259 & 0.278 & 0.722 \\
\hline DATA & 74.1 & 760 & 0.1796 & 0.8204 & 0.2836 & 0.7164 \\
\hline DATA & 74 & 760 & 0.1992 & 0.8008 & 0.3036 & 0.6964 \\
\hline DATA & 73.8 & 760 & 0.2098 & 0.7902 & 0.3143 & 0.6857 \\
\hline DATA & 73.7 & 760 & 0.2188 & 0.7812 & 0.3234 & 0.6766 \\
\hline DATA & 73.3 & 760 & 0.2497 & 0.7503 & 0.3517 & 0.6483 \\
\hline DATA & 73 & 760 & 0.2786 & 0.7214 & 0.3781 & 0.6219 \\
\hline DATA & 72.7 & 760 & 0.3086 & 0.6914 & 0.4002 & 0.5998 \\
\hline DATA & 72.4 & 760 & 0.3377 & 0.6623 & 0.4221 & 0.5779 \\
\hline DATA & 72.3 & 760 & 0.3554 & 0.6446 & 0.4331 & 0.5669 \\
\hline DATA & 72 & 760 & 0.4019 & 0.5981 & 0.4611 & 0.5389 \\
\hline DATA & 71.95 & 760 & 0.4184 & 0.5816 & 0.4691 & 0.5309 \\
\hline DATA & 71.9 & 760 & 0.4244 & 0.5756 & 0.473 & 0.527 \\
\hline DATA & 71.85 & 760 & 0.447 & 0.553 & 0.487 & 0.513 \\
\hline DATA & 71.8 & 760 & 0.4651 & 0.5349 & 0.4934 & 0.5066 \\
\hline DATA & 71.75 & 760 & 0.4755 & 0.5245 & 0.4995 & 0.5005 \\
\hline DATA & 71.7 & 760 & 0.51 & 0.49 & 0.5109 & 0.4891 \\
\hline DATA & 71.7 & 760 & 0.5669 & 0.4331 & 0.5312 & 0.4688 \\
\hline DATA & 71.75 & 760 & 0.5965 & 0.4035 & 0.5452 & 0.4548 \\
\hline DATA & 71.8 & 760 & 0.6211 & 0.3789 & 0.5652 & 0.4348 \\
\hline DATA & 71.9 & 760 & 0.6425 & 0.3575 & 0.5831 & 0.4169 \\
\hline DATA & 72 & 760 & 0.6695 & 0.3305 & 0.604 & 0.396 \\
\hline DATA & 72.1 & 760 & 0.6854 & 0.3146 & 0.6169 & 0.3831 \\
\hline
\end{tabular}




\begin{tabular}{|c|c|c|c|c|c|c|}
\hline Usage & TEMPERATURE & PRESSURE & $X$ & $X$ & $\mathrm{Y}$ & $\mathrm{Y}$ \\
\hline DATA & 72.3 & 760 & 0.7192 & 0.2808 & 0.6475 & 0.3525 \\
\hline DATA & 72.5 & 760 & 0.7451 & 0.2549 & 0.6725 & 0.3275 \\
\hline DATA & 72.8 & 760 & 0.7767 & 0.2233 & 0.702 & 0.298 \\
\hline DATA & 73 & 760 & 0.7973 & 0.2027 & 0.7227 & 0.2773 \\
\hline DATA & 73.2 & 760 & 0.8194 & 0.1806 & 0.7449 & 0.2551 \\
\hline DATA & 73.5 & 760 & 0.8398 & 0.1602 & 0.7661 & 0.2339 \\
\hline DATA & 73.7 & 760 & 0.8503 & 0.1497 & 0.7773 & 0.2227 \\
\hline DATA & 73.9 & 760 & 0.8634 & 0.1366 & 0.7914 & 0.2086 \\
\hline DATA & 74.1 & 760 & 0.879 & 0.121 & 0.8074 & 0.1926 \\
\hline DATA & 74.3 & 760 & 0.8916 & 0.1084 & 0.8216 & 0.1784 \\
\hline DATA & 74.7 & 760 & 0.9154 & 0.0846 & 0.8504 & 0.1496 \\
\hline DATA & 75.1 & 760 & 0.9367 & 0.0633 & 0.8798 & 0.1202 \\
\hline DATA & 75.3 & 760 & 0.9445 & 0.0555 & 0.8919 & 0.1081 \\
\hline DATA & 75.5 & 760 & 0.9526 & 0.0474 & 0.9038 & 0.0962 \\
\hline DATA & 75.7 & 760 & 0.9634 & 0.0366 & 0.9208 & 0.0792 \\
\hline DATA & 76 & 760 & 0.9748 & 0.0252 & 0.9348 & 0.0652 \\
\hline DATA & 76.2 & 760 & 0.9843 & 0.0157 & 0.9526 & 0.0474 \\
\hline DATA & 76.4 & 760 & 0.9903 & 0.0097 & 0.9686 & 0.0314 \\
\hline DATA & 77.15 & 760 & 1 & 0 & 1 & 0 \\
\hline
\end{tabular}

\section{Regression and selection of thermodynamic phase equilibrium model}

In Regression, the new regression models are Wilson, NRTL, and UNIQUAC (because the three models can describe the system better by choosing the experience of the thermodynamic model). The phase equilibrium model obtained by the regression of three thermodynamic models and the two element interaction parameters of sulfur dioxide and citric acid described by different thermodynamic models are obtained。

Different thermodynamic models describing the sulfur dioxide citric acid two element interaction parameter are presented below: 
Table 5 Fitting two element interaction parameter

\begin{tabular}{|c|c|c|c|}
\hline & NRTL & UNIQUAC & WILSON \\
\hline Component i & C6H8O7 & $\mathrm{C} 6 \mathrm{H} 8 \mathrm{O} 7$ & C6H8O7 \\
\hline Component $\mathrm{j}$ & $\mathrm{SO} 2$ & $\mathrm{SO} 2$ & $\mathrm{SO} 2$ \\
\hline Temperature units & $\mathrm{C}$ & $\mathrm{C}$ & $\mathrm{C}$ \\
\hline Source & R-R-1 & R-R-2 & R-R-3 \\
\hline \multicolumn{4}{|l|}{ Property units } \\
\hline AIJ & 0.061653 & -0.716431 & 2.69032 \\
\hline AJI & -2.37216 & 1.30625 & 0.298825 \\
\hline BIJ & 689.318 & -384.608 & -222.81 \\
\hline $\mathrm{BJI}$ & -446.39 & 309.229 & -13.7663 \\
\hline $\mathrm{CIJ}$ & 0.3 & 0 & 0 \\
\hline DIJ & 0 & 0 & 0 \\
\hline EIJ & 0 & 0 & 0 \\
\hline EJI & 0 & 0 & 0 \\
\hline FIJ & 0 & 0 & 0 \\
\hline FJI & 0 & 0 & 0 \\
\hline TLOWER & 40 & 40 & -273.15 \\
\hline TUPPER & 78.45 & 78.45 & 726.85 \\
\hline
\end{tabular}

By comprehensively comparing the two element interaction parameters described by the three thermodynamic models, it is found that the NRTL thermodynamic model is the most appropriate to describe the process. Therefore, the NRTL thermodynamic model is selected to do the calculation after the simulation, and the $\mathrm{SO} 2$ / citric acid two element interaction parameter is taken as the calculation model.

\section{Simulation Results}

Detailed information about the logistics components and status parameters of each node of the system is listed in table 6-7。 
Table 6 Status and components of logistics(1)

\begin{tabular}{|c|c|c|c|c|}
\hline project & $\mathrm{C} 1$ & $\mathrm{C} 2$ & $\mathrm{C} 3$ & $\mathrm{C} 4$ \\
\hline \multicolumn{5}{|l|}{ molar flow rate $\mathrm{kmol} / \mathrm{hr}$} \\
\hline water & $2.92 \mathrm{E}+05$ & $1.79 \mathrm{E}+07$ & $1.71 \mathrm{E}+07$ & $1.80 \mathrm{E}+07$ \\
\hline atmosphere & 0 & $5.48 \mathrm{E}-86$ & 28132.48 & $5.63 \mathrm{E}-86$ \\
\hline citric acid & 7875 & $4.98 \mathrm{E}+05$ & $4.98 \mathrm{E}+05$ & $4.98 \mathrm{E}+05$ \\
\hline sulfur dioxide & 0 & $5.56 \mathrm{E}-58$ & 26.96592 & $5.62 \mathrm{E}-58$ \\
\hline \multicolumn{5}{|c|}{ continued $4-10$} \\
\hline project & $\mathrm{C} 1$ & $\mathrm{C} 2$ & $\mathrm{C} 3$ & $\mathrm{C} 4$ \\
\hline \multicolumn{5}{|l|}{ Mol percentage } \\
\hline water & 0.9737098 & 0.9729554 & 0.9701911 & 0.973041 \\
\hline atmosphere & 0 & $2.98 \mathrm{E}-93$ & $1.59 \mathrm{E}-03$ & $3.05 \mathrm{E}-93$ \\
\hline citric acid & 0.0262902 & 0.0270446 & 0.0282129 & 0.0269589 \\
\hline sulfur dioxide & 0 & $3.02 \mathrm{E}-65$ & $1.53 \mathrm{E}-06$ & $3.05 \mathrm{E}-65$ \\
\hline Total flow $\mathrm{kmol} / \mathrm{hr}$ & $3.00 \mathrm{E}+05$ & $1.84 \mathrm{E}+07$ & $1.76 \mathrm{E}+07$ & $1.85 \mathrm{E}+07$ \\
\hline Total flow kg/hr & $6.77 \mathrm{E}+06$ & $4.18 \mathrm{E}+08$ & $4.05 \mathrm{E}+08$ & $4.19 \mathrm{E}+08$ \\
\hline Total flow $1 / \mathrm{min}$ & $1.01 \mathrm{E}+05$ & $6.73 \mathrm{E}+06$ & $6.34 \mathrm{E}+06$ & $6.75 \mathrm{E}+06$ \\
\hline temperature $\mathrm{C}$ & 20 & 93.48749 & 72.41015 & 94.61731 \\
\hline pressure bar & 1.01325 & 1.01325 & 1.01325 & 0.8106 \\
\hline
\end{tabular}

Table 7 Status and components of each logistics (2)

\begin{tabular}{|c|c|c|c|c|}
\hline $\begin{array}{c}\text { molar flow rate } \\
\mathrm{kmol} / \mathrm{hr}\end{array}$ & CLEANGAS & GAS & GASW & PRODUCT \\
\hline water & $7.90 \mathrm{E}+05$ & 0 & $2.10 \mathrm{E}+06$ & $1.25 \mathrm{E}+06$ \\
\hline atmosphere & 3090.025 & 31222.5 & 0 & 28132.48 \\
\hline citric acid & $2.26 \mathrm{E}-04$ & 0 & 0 & $2.12 \mathrm{E}-04$ \\
\hline sulfur dioxide & 0.5340799 & 27.5 & 0 & 26.96592 \\
\hline Mol percentage & & & & \\
\hline water & 0.9961051 & 0 & 1 & 0.9779331 \\
\hline atmosphere & $3.89 \mathrm{E}-03$ & 0.99912 & 0 & 0.0220457 \\
\hline citric acid & $2.85 \mathrm{E}-10$ & 0 & 0 & $1.66 \mathrm{E}-10$ \\
\hline sulfur dioxide & $6.73 \mathrm{E}-07$ & $8.80 \mathrm{E}-04$ & 0 & $2.11 \mathrm{E}-05$ \\
\hline Total flow $\mathrm{kmol} / \mathrm{hr}$ & $7.93 \mathrm{E}+05$ & 31250 & $2.10 \mathrm{E}+06$ & $1.28 \mathrm{E}+06$ \\
\hline Total flow $\mathrm{kg} / \mathrm{hr}$ & $1.43 \mathrm{E}+07$ & $9.06 \mathrm{E}+05$ & $3.78 \mathrm{E}+07$ & $2.33 \mathrm{E}+07$ \\
\hline Total flow $1 / \mathrm{min}$ & $4.06 \mathrm{E}+08$ & $1.42 \mathrm{E}+07$ & $1.08 \mathrm{E}+09$ & $8.01 \mathrm{E}+08$ \\
\hline temperature C & 100.6276 & 60 & 105 & 94.01374 \\
\hline pressure bar & 1.01325 & 1.01325 & 1.01325 & 0.8106 \\
\hline
\end{tabular}

Enter the necessary given conditions and restrictions, as aforesaid under the assumption that by running the above model, the amount of flue gas: $700000 \mathrm{Nm} 3 / \mathrm{h}$ per hour processing as shown in the table of the flue gas composition, the system consumes citrate $41 \mathrm{~kg} / \mathrm{h}$, water $16.2 \mathrm{t} / \mathrm{h}$, liquid gas $7.5 \mathrm{~L} / \mathrm{Nm} 3$, desulfurization efficiency of the system can reach $95 \%$.

5 simulation results analysis3.1 Influence of inlet flue gas $\mathrm{SO} 2$ concentration on desulfurization efficiency

Sensitivity analysis of the model is carried out, and other process conditions are kept constant. The inlet flue gas SO2 concentration is adjusted, and the relationship between the flue gas SO2 concentration and the desulfurization efficiency is obtained, as shown in figure 1. Calculation 
conditions: the amount of flue gas is $700000 \mathrm{Nm} 3 / \mathrm{h}$, the absorption liquid circulation is $5250 \mathrm{~m} 3 / \mathrm{h}$, the liquid gas ratio is $7.5 \mathrm{~L} / \mathrm{m} 3$, and the citrate absorption liquid flow rate is $1008 \mathrm{~kg} / \mathrm{h}$.

Can be seen from Figure 2, in the same condition, the desulfurization efficiency of the system decreased with the increase of entrance flue gas $\mathrm{SO} 2$ concentration, flue gas $\mathrm{SO} 2$ concentration increased from $1000 \mathrm{mg} / \mathrm{Nm} 3$ to $5500 \mathrm{mg} / \mathrm{Nm} 3$, the desulfurization efficiency is reduced from $98 \%$ to $88.5 \%$. This is mainly due to the influence of the increase of SO2 concentration in the gas phase on the interphase mass transfer effect。

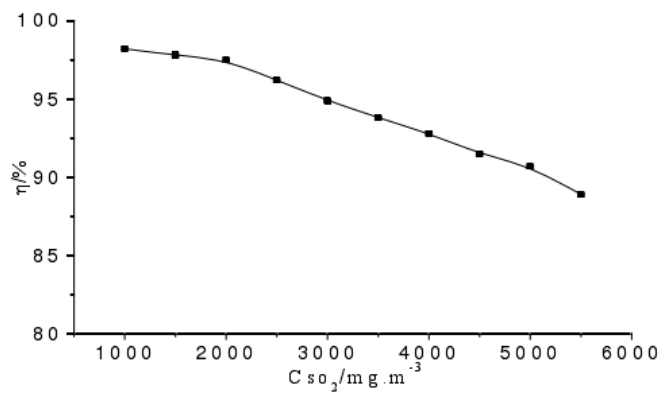

Fig.2. Effect of inlet flue gas SO2 concentration on desulfurization efficiency3.2liquidEffect of gas ratio on desulfurization efficiency

Sensitivity analysis of the model is carried out, and other process conditions are kept constant, and the ratio of liquid to gas is adjusted. The influence diagram of liquid gas ratio on desulfurization efficiency is shown as shown in figure 3. Calculation conditions: the amount of flue gas is 700000 $\mathrm{Nm} 3 / \mathrm{h}$, the inlet flue gas SO2 concentration is $2.73 \mathrm{~g} / \mathrm{Nm} 3$, and the citrate flow is $1008 \mathrm{~kg} / \mathrm{h}$. As can be seen from Figure 3, under the same conditions, the desulfurization efficiency increases with the increase of liquid gas ratio. The ratio of liquid to gas increases by about $11.5 \mathrm{~L} / \mathrm{m} 3$ from $2.5 \mathrm{~L} / \mathrm{m} 3$, and the desulfurization efficiency increases from $63 \%$ to $97 \%$. Under actual operation conditionConsidering the desulfurization efficiency and operation cost, the ratio of liquid to gas in the flue gas desulfurization system of citrate method is chosen $7.5 \mathrm{~L} / \mathrm{m} 3-10 \mathrm{~L} / \mathrm{m} 3$, which can meet the requirements of desulfurization efficiency greater than $95 \%$.

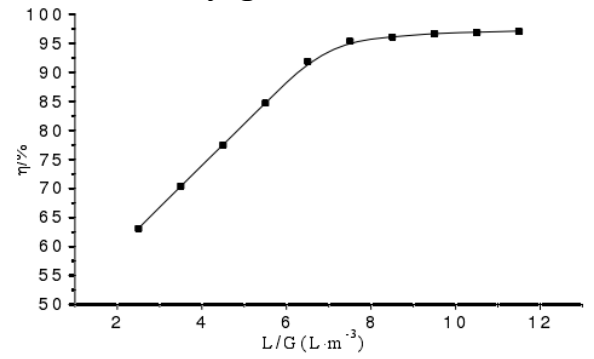

Fig.3. Effect of liquid gas ratio on desulfurization efficiency

\section{Influence of flue gas volume on desulfurization efficiency}

The sensitivity analysis of the model, the constant of other process conditions, the adjustment of the inlet flue gas amount, and the influence of the amount of flue gas on the desulfurization efficiency are shown as shown in figure 4. Calculation conditions: the absorption liquid circulation is $5250 \mathrm{~m} 3 / \mathrm{h}$, the inlet flue gas SO2 concentration is $2.73 \mathrm{~g} / \mathrm{Nm} 3$, the citric acid salt flow rate is $1008 \mathrm{~kg} / \mathrm{h}$. As can be seen from Figure 4, under the same conditions, the desulfurization efficiency of the system decreases with the increase of the amount of flue gas, the amount of flue gas increases from $250000 \mathrm{Nm} 3 / \mathrm{h}$ to $700000 \mathrm{Nm} 3 / \mathrm{h}$, and the desulfurization efficiency is reduced from $99 \%$ to $95 \%$. For a specific absorption tower, under the condition of other conditions unchanged, increasing the amount of flue gas, desulfurization efficiency will decline, on the contrary, efficiency will rise. 


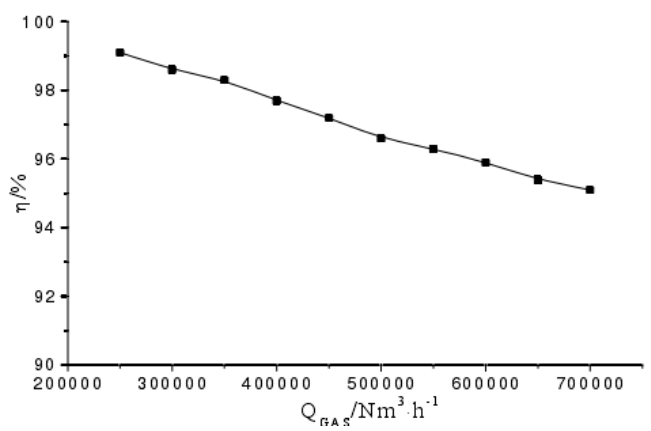

Fig.4 .Effect of flue gas volume on desulfurization efficiency

\section{Conclusion}

In this paper, the theoretical analysis of the absorption of sulfur dioxide by citrate method and the numerical simulation of absorption tower and desorption tower in the main part of the desulfurization system are carried out, and the following conclusions are obtained:

(1) draw the process flow chart and equipment connection diagram, and understand the citrate method more directly.

(2) the phase equilibrium experimental data regression to two yuan of sulfur dioxide and citric acid parameters, of which two yuan NRTL thermodynamic model of interaction parameters under AIJ $=0.061653$ description, can well describe the actual situation. The citrate method desulfurization process of materialbalance, the results are as follows: the amount of flue gas per hour when dealing with $700000 \mathrm{Nm} 3 / \mathrm{h}$ system consumes citrate $41 \mathrm{~kg} / \mathrm{h}$, water $16.2 \mathrm{t} / \mathrm{h}$, oxidation air requirement for $2000 \mathrm{~kg} / \mathrm{h}$, liquid gas ratio $7.5 \mathrm{~L} / \mathrm{Nm} 3$, desulfurization efficiency of the system can reach $95 \%$.

Through the simulation analysis, it is concluded that the desulfurization efficiency of the system decreases with the increase of inlet flue gas SO2 concentration. When the concentration of SO2 in the flue gas is below $3000 \mathrm{mg} / \mathrm{m} 3$, the desulfurization efficiency can be guaranteed to be above $95 \%$. Increased with the increase of the ratio of liquid to gas, liquid gas ratio of 7.5 and above, can achieve a good desulphurization effect, and after the liquid gas ratio increases, desulfurization efficiency changed little; reduce with increase of amount of flue gas and flue gas in the amount can be within $700000 \mathrm{~m} 3 / \mathrm{h}$ to get better effect of desulfurization; absorption amount increased with the increase of citric acid absorption liquid, but increased to a certain extent after the change are not obvious.

The optimum conditions are as follows: the inlet gas concentration is $3000 \mathrm{mg} / \mathrm{m} 3$, the flue gas volume is $700000 \mathrm{~m} 3 / \mathrm{h}$; the absorption liquid gas ratio is 7.5 ; the citrate consumption is $41 \mathrm{~kg} / \mathrm{h}$. In actual production, the actual situation needs to be considered.

\section{References}

[1] Meng Lingai. Polyamine solution of sulfur dioxide in flue gas of [D]. Xi'an: Xi'an University Of Architecture And Technology, 2008.

[2] Xie Tao. The film absorption method of smelting flue gas of low concentration SO2 research [D]. Xi'an: Xi'an University Of Architecture And Technology, 2005.

[3] Liu Feng. Study on the mass transfer process of hollow fiber absorption of sulfur dioxide [D]. Xi'an: Xi'an University Of Architecture And Technology, 2004.

[4] Wang Zhaoqi. Study on treatment of low concentration sulfur dioxide by ultrasonic membrane absorption [D]. Xi'an: Xi'an University Of Architecture And Technology, 2006.

[5] Liu Zhao. Study on flue gas desulfurization with sodium citrate [D]. Beijing: Beijing University of Chemical Technology, 2013.

[6] Wang Keliang. Experimental study on Microwave desorption of sulfur dioxide in citrate solution [D]. Xi'an: Xi'an University Of Architecture And Technology, 2006. 